\title{
Pengembangan Perangkat Pembelajaran Matematika Berbasis Model Core untuk Memfasilitasi Kemampuan Pemecahan Masalah Matematis Peserta Didik SMP
}

\author{
Junitasari $^{1}$, Yenita Roza ${ }^{2}$, Putri Yuanita ${ }^{3}$ \\ 1, 2, 3 Dosen Program Studi Magister Pendidikan Matematika, Universitas Riau \\ junitasari6596@grad.unri.ac.id
}

\begin{abstract}
This research is motivated by the low ability of students to solve mathematical problems and the absence of learning tools that are in accordance with the 2013 curriculum. in the standard 2013 curriculum process so that students' mathematical problem solving abilities are not well honed. This study aims to produce learning tools (syllabus, RPP, LKPD) based on the CORE model that can facilitate valid and practical students' mathematical problem solving abilities. This research is a research and development study. The development model used refers to the ADDIE development model which has stages, namely Analysis, Design, Development, Implementation, Evaluation. The subjects in this study were 8 students of SMP Negeri 1 Rokan IV Koto Kab. Rokan Hulu. The instrument used was a validity instrument in the form of a validation sheet and a practicality instrument in the form of a student response questionnaire. The results of the validity data analysis showed that the average validation of the syllabus was $93.63 \%$ with very valid criteria; the average validation of RPP is $95.60 \%$ with very valid criteria; and the average LKPD validation is $91.49 \%$ with very valid criteria. The results of practicality data analysis, the results of the readability of the learning tools were $89.07 \%$ with very practical criteria. Overall, it can be concluded that the learning tools developed have met the valid and practical criteria.
\end{abstract}

Keywords: Learning media, CORE, mathematical problem solving ability

\begin{abstract}
Abstrak
Penelitian ini dilatarbelakangi oleh rendahnya kemampuan pemecahan masalah matematis peserta didik serta belum adanya perangkat pembelajaran yang sesuai dengan kurikulum 2013. Berdasarkan hasil wawancara, observasi, dokumentasi, dan tes kemampuan pemecahan masalah matematis yang peneliti lakukan, diperoleh fakta bahwa perangkat pembelajaran yang dimiliki guru belum mengacu pada standar proses kurikulum 2013 sehingga kemampuan pemecahan masalah matematis peserta didik tidak terasah dengan baik. Penelitian ini bertujuan untuk menghasilkan perangkat pembelajaran (Silabus, RPP, LKPD) berbasis model CORE yang dapat memfasilitasi kemampuan pemecahan masalah matematis peserta didik yang valid dan praktis. Penelitian ini adalah penelitian pengembangan (research and development). Model pengembangan yang digunakan mengacu pada model pengembangan ADDIE yang memiliki tahap yaitu Analysis, Design, Development, Implementation, Evaluation. Subjek dalam penelitian ini adalah 8 orang peserta didik SMP Negeri 1 Rokan IV Koto Kab. Rokan Hulu. Instrumen yang digunakan adalah instrumen validitas berupa lembar validasi dan instrumen praktikalitas berupa angket respon peserta didik. Hasil analisis data validitas, diperoleh rata-rata validasi silabus yaitu 93,63\% dengan kriteria sangat valid; rata-rata validasi RPP yaitu 95,60\% dengan kriteria sangat valid; dan rata-rata validasi LKPD yaitu 91,49\% dengan kriteria sangat valid. Hasil analisis data praktikalitas, hasil keterbacaan perangkat pembelajaran yaitu $89,07 \%$ dengan kriteria sangat praktis. Secara keseluruhan dapat disimpulkan bahwa perangkat pembelajaran yang dikembangkan telah memenuhi kriteria valid dan praktis.
\end{abstract}

Kata kunci: Perangkat Pembelajaran, Model CORE, Kemampuan Pemecahan Masalah Matematis

Copyright (c) 2021 Junitasari, Yenita Roza, Putri Yuanita

$\triangle$ Corresponding author: Junitasari

Email Address: junitasari6596@grad.unri.ac.id (Kampus Bina Widya KM 12,5, Simpang Baru, Pekanbaru, Riau)

Received 17 Desember 2020, Accepted 12 Maret 2021, Published 27 Maret 2021

\section{PENDAHULUAN}

Matematika merupakan salah satu pelajaran yang sangat penting diajarkan di sekolah mulai sejak sekolah dasar sampai sekolah menengah baik tingkat pertama maupun tingkat atas, bahkan sampai perguruan tinggi. Pentingnya pembelajaran matematika disampaikan oleh Cornelius (Abdurrahman, 
2012) bahwa perlunya peserta didik belajar matematika yaitu sebagai: (1) sarana berpikir yang jelas dan logis; (2) sarana untuk memecahkan masalah dalam kehidupan sehari-hari; (3) sarana mengenal polapola hubungan dan generalisasi pengalaman; (4) sarana untuk mengembangkan kreativitas; (5) sarana untuk meningkatkan kesadaran terhadap perkembangan budaya. Matematika mempunyai peran penting dalam kehidupan manusia, seperti pada perkembangan ilmu pengetahuan, perdagangan dan industri. Matematika merupakan suatu ilmu pengetahuan yang berperan penting dalam melatih kemampuan peserta didik salah satunya yaitu kemampuan pemecahan masalah matematis.

Kemampuan pemecahan masalah merupakan salah satu tujuan pembelajaran matematika pada kurikulum 2013, yaitu menggunakan penalaran pada sifat, melakukan manipulasi matematika baik dalam penyederhanaan, maupun menganalisa komponen yang ada dalam pemecahan masalah dengan kontek matematika maupun di luar matematika (Permendikbud Nomor 58 Tahun 2014 tentang Kurikulum SMP, n.d.). Pembelajaran dalam kurikulum 2013 merupakan pembelajaran berbasis aktivitas yang memberikan kesempatan kepada peserta didik untuk aktif mencari, mengolah, mengkonstruksi, dan menggunakan pengetahuan dalam pemecahan masalah. Tujuan kurikulum 2013 sejalan dengan tujuan National Council of Teachers of Mathematics (NCTM, 2000) menjelaskan tentang tujuan pembelajaran matematika diantaranya adalah mengembangkan kemampuan: (1) kemampuan pemecahan masalah, (2) kemampuan komunikasi, (3) kemampuan koneksi, (4) kemampuan penalaran, dan (5) kemampuan representasi.

Kemampuan pemecahan masalah matematis di Indonesia masih membutuhkan pembenahan dan perhatian khusus. Hasil analisis yang dilakukan oleh dua studi internasional, yaitu Trends in International Mathematics and Science Study (TIMSS) dan Programing for International Student Assessment (PISA) membuktikan bahwa kemampuan pemecahan masalah di Indonesia masih rendah. Kemendikbud mengemukakan bahwa laporan hasil TIMSS menunjukkan peserta didik Indonesia berada pada rangking rendah dalam kemampuan: (1) memahami informasi yang kompleks; (2) teori, analisis, dan pemecahan masalah; (3) pemakaian alat, prosedur dan pemecahan masalah; dan (4) melakukan investigasi (Haholo, 2016). Sementara itu hasil riset PISA pada tahun 2012 skor matematika peserta didik Indonesia menduduki peringkat 64 dari 65 negara dengan skor 375(OECD, 2014). Soal-soal matematika dalam studi PISA lebih banyak mengukur kemampuan penalaran, pemecahan masalah, dan berargumentasi. Lebih dari setengah peserta didik Indonesia yaitu 75,7\% memiliki kinerja rendah dan hanya mampu menyelesaikan soal yang paling sederhana dimana konteksnya masih bersifat umum. Terdapat $0,1 \%$ yang mampu mengembangkan dan mengerjakan pemodelan matematika yang menuntut keterampilan berpikir dan pemecahan masalah.

Kenyataan menunjukkan bahwa kemampuan pemecahan masalah matematis peserta didik masih tergolong rendah. Hal ini dapat dilihat dari hasil penelitian Ulya (Ulya, 2016) menunjukkan bahwa kemampuan pemecahan masalah matematis peserta didik masih kurang baik, karena peserta didik selalu mempunyai kendala dalam menuliskan penyelesaian masalah ke dalam bahasa matematika dan belum mampu melakukan pengecekan masalah kembali. Begitu juga dengan hasil penelitian Linggar 
dan Budi (Linggar, G., M., Budi, 2016) menunjukkan bahwa persentase kesalahan peserta didik pada indikator memahami masalah 34,93\%, merencanakan pemecahan masalah 35,47\%, melaksanakan rencana pemecahan masalah 53,6\% dan memeriksa kembali 60,8\%. Hal ini menunjukkan bahwa rendahnya kemampuan pemecahan masalah matematis peserta didik.

Berdasarkan hasil tes yang dilaksanakan di SMP Negeri 1 Rokan IV Koto, diperoleh bahwa 43 dari 49 peserta didik memiliki kemampuan pemecahan masalah matematis rendah. Rendahnya kemampuan pemecahan masalah matematis peserta didik terlihat pada saat peserta didik mengerjakan 2 soal pemecahan masalah, peserta didik tidak bisa menjawab soal tersebut. Pada jawaban peserta didik terlihat bahwa terdapat beberapa indikator yang tidak dapat dicapai oleh peserta didik, diantaranya memahami masalah, merencanakan penyelesaian, menyelesaikan sesuai rencana, dan memeriksa kembali. Penyebabnya rendahnya kemampuan pemecahan masalah matematis dikarenakan peserta didik melakukan kesalahan dalam memahami masalah (soal), kesalahan dalam merencanakan penyelesaian, kesalahan dalam perhitungan, serta kesalahan dalam memeriksa kembali langkah demi langkah yang telah dikerjakan sehingga lupa membuat kesimpulan yang diperoleh. Guru harus membiasakan peserta didik dalam menyelesaikan soal dengan tahap demi tahap yang sesuai dengan indikator kemampuan pemecahan masalah matematis peserta didik.

Permasalahan kemampuan pemecahan masalah matematis ini perlu dicari solusi agar tidak ditemukan lagi peserta didik yang memiliki kemampuan pemecahan masalah matematis yang rendah. Cara yang dapat dilakukan adalah dengan melaksanakan perbaikan pada proses pembelajaran. Salah satu penentu keberhasilan proses pembelajaran dan keberhasilan dalam pencapaian tujuan pembelajaran matematika adalah perangkat pembelajaran. Mengimplementasi tujuan pembelajaran matematika dalam membangun kemampuan pemecahan masalah membutuhkan pembelajaran yang dapat melibatkan siswa secara aktif. Guru sebagai fasilitator dalam pembelajaran harus mampu menyediakan perangkat pembelajaran yang dirancang untuk meningkatkan kemampuan pemecahan masalah pada peserta didik. Perangkat pembelajaran yang harus disiapkan oleh guru antara lain silabus, Rencana Pelaksanaan Pembelajaran (RPP), bahan ajar, media pembelajaran dan lain sebagainya, yang dapat menunjang pembelajaran. Pembelajaran yang berlangsung harus berpusat pada peserta didik yang dapat dibantu dengan ketersediaan bahan ajar yaitu Lembar Kerja Peserta Didik (LKPD).

Guru diharapkan mampu menyediakan perangkat pembelajaran dengan pendekatan yang tepat agar tujuan pembelajaran matematika tercapai dengan baik. Guru juga diharapkan mampu mengaitkan permasalahan pembelajaran dengan dunia nyata peserta didik agar pengimplementasian pembelajaran tercapai. Salah satu perangkat pembelajaran yang harus dikembangkan sesuai dengan pendekatan pembelajaran yang baik adalah LKPD, dengan adanya LKPD yang dikembangkan oleh guru sesuai dengan pendekatan yang tepat maka diharapkan tujuan pembelajaran tercapai dengan baik. Salah satu upaya guru yang dapat dilakukan untuk meningkatkan kemampuan pemecahan masalah matematis peserta didik yaitu dengan mengembangkan LKPD yang lebih menekankan keaktifan pada diri peserta didik dan memotivasi peserta didik untuk dapat memecahkan masalah. LKPD adalah lembar-lembar 
berisi tugas yang harus dikerjakan peserta didik. Andi (Prastowo, 2010) menjelaskan LKPD merupakan materi ajar yang sudah dikemas sedemikian rupa, sehingga peserta didik diharapkan dapat mempelajari materi ajar secara mandiri. Pengembangan LKPD dilakukan agar pembelajaran menjadi efektif, efisien dan tidak melenceng dari kompetensi yang akan dicapai.

Model pembelajaran matematika yang dapat mengkondisikan peserta didik aktif dalam belajar matematika sehingga dapat meningkatkan kemampuan pemecahan masalah matematis peserta didik menjadi lebih baik yaitu model pembelajaran CORE. Menurut Shoimin (Shoimin, 2014) proses pembelajaran dengan menggunakan model pembelajaran CORE mengharapkan peserta didik mampu mengkonstruksikan pengetahuan sendiri dengan cara menghubungkan dan mengorganisasikan pengetahuan yang lama dengan pengetahuan baru. Menurut Ulfa (Ulfa Aulia, 2015) tahapan model pembelajaran CORE menawarkan sebuah proses pembelajaran yang memberikan ruang bagi peserta didik untuk berpendapat, mencari solusi serta membangun pengetahuannya sendiri. Menurut Suyatno model CORE merupakan sebuah model yang mencakup empat tahapan yaitu Connecting Peserta didik diajak untuk menghubungkan pengetahuan baru yang akan dipelajari dengan pengetahuan lama yang telah dipelajari (Suyatno, 2009). Organizing membawa peserta didik mengorganisasikan pengetahuannya. Reflecting peserta didik dilatih untuk dapat menjelaskan kembali informasi yang telah mereka dapatkan. Extending dimana pengetahuan peserta didik akan diperluas. Tahapan pada pembelajaran model CORE juga memberikan ruang kepada peserta didik untuk berpendapat $\mathrm{n}$ mencari solusi serta membangun sendiri pengetahuannya (Noorlaila, Danaryanti, A., \& Mawaddah, 2018).

Pemilihan dan penggunaan model pembelajaran yang tepat yang dapat memfasilitasi dan meningkatkan kemampuan pemecahan masalah matematis peserta didik yaitu model connecting, organizing, reflecting, extending (CORE). Menurut pada proses pembelajaran dengan menggunakan model pembelajaran CORE, difokuskan pada peserta didik untuk berpikir menghubungkan, mengorganisasikan, dan mengembangkan informasi dan juga peserta didik dilatih untuk aktif (Konita, M., Asikin, M. \& Asih, 2019). Penelitian yang telah dilakukan oleh Sa'adah tentang pengembangan perangkat ajar model CORE pendekatan metakognitif untuk meningkatkan kemampuan pemecahan masalah geometri kelas VIII diperoleh perangkat yang valid dan praktis (Sa'adah, D., Masrukan, M., \& Kuniasih, 2017). Azizah mengemukakan bahwa hasil pembelajaran dengan model CORE berlangsung efektif (Azizah, L., Mariani, S., \& Rochmad, 2012). Kemudian penelitian yang dilakukan oleh Humairah juga menunjukkan bahwa pembelajaran dengan model CORE lebih baik dari pembelajaran menggunakan model konvensional (Al Humaira, 2014).

Perencanaan proses pembelajaran matematika yang sesuai dapat membantu tercapainya tujuan pembelajaran matematika. Seperti yang diungkapkan oleh kunandar guru yang baik adalah guru yang menyusun perencanaan pembelajaran sebelum melaksanakan pembelajaran di kelas (Kunandar, 2014). Pengembangan perangkat pembelajaran matematika berbasis model CORE penting dilakukan oleh guru, karena dengan pengembangan perangkat pembelajaran matematika yang baik diharapkan membuat pembelajaran di kelas menjadi lebih baik. Model CORE berperan sebagai alur yang menjembatani 
peserta didik untuk mengeksplor kemampuannya dalam mengatasi permasalahan yang diberikan. Pembelajaran model CORE telah memberikan keluasan yang optimal bagi peserta didik untuk mengembangkan dan melatih kemampuan pemecahan masalah, sehingga berpengaruh langsung terhadap kemampuan pemecahan masalah matematis peserta didik. Perangkat pembelajaran matematika yang berbasis model CORE dapat memupuk kemampuan pemecahan masalah matematis peserta didik, karena model CORE ini menawarkan sebuah proses pembelajaran yang memberi ruang bagi peserta didik untuk berpendapat, melatih daya ingatnya terhadap suatu konsep, mencari solusi, dan membangun pengetahuannya sendiri. Perangkat pembelajaran matematika berbasis model CORE melibatkan peserta didik lebih aktif dalam proses pembelajaran, memudahkan peserta didik dalam mempelajari dan mendalami konsep, melatih peserta didik berpikir lebih kreatif dalam menemukan berbagai strategi pemecahan masalah, memantapkan konsep yang dimiliki peserta didik, serta meningkatkan minat peserta didik untuk belajar.

Berawal dari beberapa permasalahan yang terjadi, maka perlu adanya pengembangan perangkat pembelajaran matematika yang memfasilitasi kemampuan pemecahan masalah matematis peserta didik. Peneliti akan meneliti "Pengembangan perangkat pembelajaran matematika berbasis model CORE untuk memfasilitasi kemampuan pemecahan masalah matematis peserta didik".

\section{METODE}

Penelitian ini adalah penelitian pengembangan (research and development). Model pengembangan yang digunakan dalam penelitian ini adalah model pengembangan ADDIE. Menurut Endang berdasarkan langkah-langkah pengembangan produk, model ADDIE lebih rasional dan lebih lengkap daripada model pengembangan lain (Mulyatiningsih, 2012). Benny menyatakan bahwa model desain sistem pembelajaran yang memperlihatkan tahapan-tahapan dasar desain sistem pembelajaran yang sederhana dan mudah dipelajari adalah model ADDIE yang terdiri dari 5 tahap yaitu Analysis, Design, Development, Implementation, dan Evaluation (Benny A. Pribadi, 2010). Bagan dari model pengembangan dapat dilihat pada gambar 1 .

Tahap analysis yang dilakukan peneliti yaitu (1) analisis perangkat pembelajaran, peneliti melakukan analisis terhadap perangkat pembelajaran yang digunakan di sekolah. Pada tahap ini peneliti melakukan teknik wawancara dan studi dokumentasi. Analisis ini bertujuan untuk menentukan masalah dasar yang terjadi pada perangkat pembelajaran; (2) analisis materi, peneliti mengidentifikasi materi pembelajaran bangun ruang sisi datar, peneliti menentukan cakupan materi pembelajaran. Analisis ini dilakukan untuk menentukan isi dan materi pelajaran yang diperlukan, sehingga dapat membantu peserta didik dalam memfasilitasi kemampuan pemecahan masalah matematis; (3) analisis karakteristik peserta didik, peneliti melakukan telaah tentang karakteristik peserta didik sebagai pengguna perangkat pembelajaran yang dikembangkan dalam proses pembelajaran. Peneliti melakukan studi pendahuluan tes kemampuan pemecahan masalah matematis. 


\section{Tahap Analysis}

1. Analisis perangkat pembelajaran

2. Analisis materi

3. Analisis karakteristik peserta didik

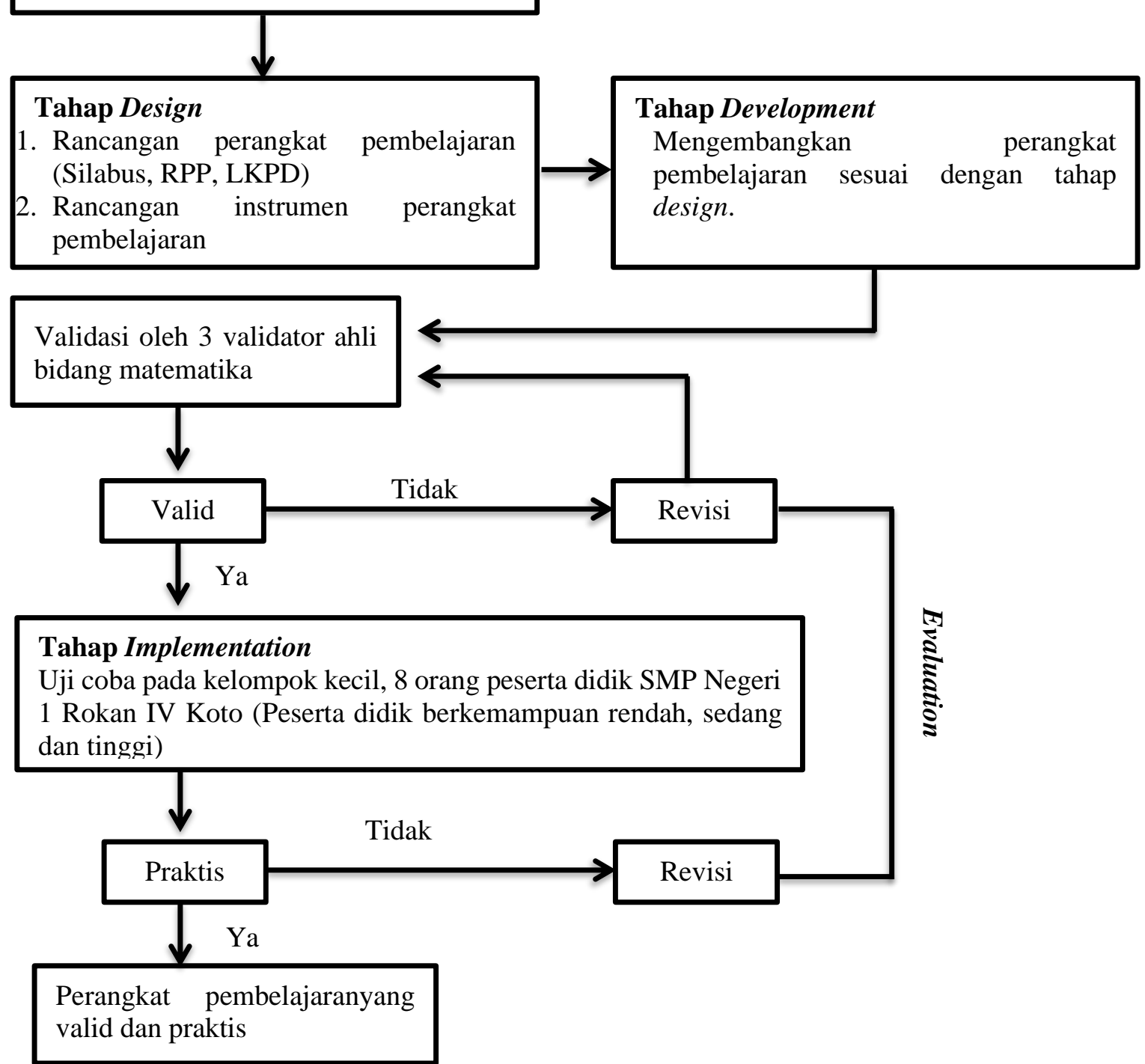

Gambar 1. Bagan Model Pengembangan ADDIE

Tahap design, peneliti membuat rancangan awal perangkat pembelajaran yang berupa silabus, RPP, dan LKPD yang berbasis model CORE. Rancangan silabus dan RPP sesuai dengan Permendikbud Nomor 22 Tahun 2016, sedangkan LKPD yang dirancang sesuai dengan tahapan model CORE. Selanjutnya tahap development, peneliti mengembangkan perangkat pembelajaran sesuai dengan rancangan awal. Perangkat pembelajaran yang telah dikembangkan divalidasi oleh tiga orang validator yaitu dua dosen pendidikan matematika dan satu guru matematika di sekolah. Perangkat pembelajaran dikatakan valid jika persentase validasi lebih dari 70\% (Akbar, 2013). Tahap implementation, setelah perangkat pembelajaran dinyatakan valid, peneliti melakukan uji kelompok kecil terhadap LKPD yang dikembangkan kepada 8 orang peserta didik dengan kemampuan heterogen untuk melihat keterbacaan 
LKPD. Pada tahap evaluation, peneliti merevisi perangkat pembelajaran sesuai dengan saran validator dan saran dari peserta didik pada saat uji coba terbatas.

Instrumen pengumpulan data yang digunakan untuk mengumpul data dalam penelitian ini yaitu instrumen validitas dan instrumen praktikalitas. Instrumen validitas adalah lembar validasi perangkat (Silabus, RPP, dan LKPD). Instrumen praktikalitas adalah angket respon peserta didik terhadap penggunaan LKPD. Bentuk lembar validasi dan angket respon peserta didik yang digunakan yaitu angket terstruktur dan tidak terstruktur. Teknik pengumpulan data dalam penelitian ini adalah angket, yaitu angket lembar validasi dan angket respon peserta didik.

\section{HASIL DAN DISKUSI}

Penelitian ini menghasilkan perangkat pembelajaran berbasis model CORE materi bangun ruang sisi datar kelas VIII SMP/ MTs. Model pengembangan yang digunakan yaitu model ADDIE. Pada tahap analysis peneliti melakukan wawancara terhadap empat orang guru matematika tingkat SMP/MTs di Kecamatan Rokan IV Koto Kabupaten Rokan Hulu. Aspek wawancara terdiri dari keterlibatan guru dalam menyusun perangkat pembelajaran dan sumber belajar yang digunakan.

Hasil wawancara yang dilakukan dengan empat guru matematika tentang keterlibatan guru dalam mengembangkan perangkat pembelajaran sebagai berikut: tiga dari empat guru tersebut menggunakan perangkat pembelajaran dari musyawarah guru mata pelajaran (MGMP) dan internet. Alasan guru tidak mengembangkan perangkat secara mandiri, guru kesulitan dalam merumuskan indikator pencapaian kompetensi (IPK), guru kesulitan merumuskan tujuan pembelajaran, dan guru kesulitan menyesuaikan model pembelajaran dengan kegiatan pembelajaran. Berdasarkan hasil wawancara yang dilakukan peneliti dengan guru berkaitan dengan sumber belajar yang digunakan sebagai berikut: keempat guru mengatakan sumber belajar yang digunakan adalah buku cetak yang diterbitkan oleh kemendikbud dan penerbit swasta, serta modul yang dibeli sekolah pada penerbit. Dimana modul tersebut berisi materi ringkas, contoh soal, dan soal.

Analisis materi, peneliti mengidentifikasi materi yang akan dikembangkan. Penelitian ini peneliti memilih materi bangun ruang sisi datar dengan KD. 3.9 dan 4.9. peneliti juga menyusun rencana kegiatan pembelajaran menjadi enam pertemuan yaitu (1) Luas permukaan kubus dan balok; (2) Volume kubus dan balok; (3) Luas permukaan prisma; (4) Volume prisma; (5) Luas permukaan limas; (6) Volume limas. Analisis peserta didik, peneliti melakukan studi pendahuluan tes kemampuan pemahaman matematis pada materi bangun ruang sisi datar. Subyek penelitian ini yaitu peserta didik kelas VIII yang berusia 12-13 tahun. Menurut teori Jean Piaget, dimana peserta didik sudah mampu untuk berpikir abstrak, mampu menggunakan nalarnya, mampu mengkonstruksikan pengetahuan sendiri, dan dapat menyesuaikan diri dalam menerima pelajaran yang sudah dipelajari maupun yang belum dipelajari. Peneliti memperoleh data bahwa kemampuan pemecahan masalah matematis yang dimiliki peserta didik masih tergolong rendah terlihat pada tabel 1. 
Tabel 1. Hasil Analisis Kemampuan Pemecahan Masalah Matematis Peserta Didik

\begin{tabular}{|l|c|l|}
\hline $\begin{array}{c}\text { Indikator Kemampuan } \\
\text { Pemecahan Masalah } \\
\text { Matematis }\end{array}$ & Persentase & \multicolumn{1}{|c|}{ Hasil Analisis } \\
\hline Memahami masalah & $34,7 \%$ & $\begin{array}{l}\text { Peserta didik belum mampu memahami masalah yang } \\
\text { diberikan dan mengidentifikasi apa yang diketahui dan } \\
\text { ditanyakan dengan tepat. }\end{array}$ \\
\hline $\begin{array}{l}\text { Merencanakan } \\
\text { penyelesaian }\end{array}$ & $71,4 \%$ & $\begin{array}{l}\text { Peserta didik belum mampu menggunakan konsep dan rumus } \\
\text { berdasarkan masalah yang diberikan. }\end{array}$ \\
\hline $\begin{array}{l}\text { Menyelesaikan masalah } \\
\text { sesuai rencana }\end{array}$ & $62,2 \%$ & $\begin{array}{l}\text { Peserta didik belum mampu melakukan perhitungan dan } \\
\text { menyelesaikan masalah dengan benar. }\end{array}$ \\
\hline Memeriksa kembali & $81,6 \%$ & $\begin{array}{l}\text { Peserta didik belum mampu memberikan kesimpulan } \\
\text { berdasarkan masalah yang diberikan. }\end{array}$ \\
\hline
\end{tabular}

Tahap design, peneliti menyiapkan rancangan awal perangkat pembelajaran berupa silabus, RPP, dan LKPD. Rancangan silabus dan RPP sesuai dengan Permendikbud Nomor 22 Tahun 2016, sedangkan LKPD yang dirancang sesuai dengan tahapan model CORE. Selanjutnya tahap development, peneliti mengembangkan perangkat pembelajaran sesuai dengan rancangan awal. Silabus dikembangkan sesuai dengan rancangan awal dan mengacu kepada permendikbud No.22 Tahun 2016 tentang standar proses. Silabus yang dikembangkan hanya pada materi bangun ruang sisi datar enam pertemuan dengan menggunakan model CORE. Perangkat pembelajaran yang telah dikembangkan divalidasi oleh tiga orang validator. Berikut hasil validasi silabus pada tabel 2.

Tabel 2. Hasil Validasi Silabus

\begin{tabular}{|l|c|}
\hline \multicolumn{1}{|c|}{ Indikator Penilaian } & Rata-rata \\
\hline Kelengkapan identitas silabus & $100 \%$ \\
\hline Kejelasan Kompetensi Inti (KI) dan Kompetensi Dasar (KD) & $100 \%$ \\
\hline Kesesuaian materi pembelajaran & $94,45 \%$ \\
\hline Kejelasan rumusan Indikator Pencapaian Kompetensi (IPK) & $100 \%$ \\
\hline Kesesuaian kegiatan pembelajaran dengan standar proses dan model CORE & $77,78 \%$ \\
\hline Kesesuaian penilaian hasil belajar & $91,67 \%$ \\
\hline $\begin{array}{l}\text { Kesesuaian sumber belajar dengan tujuan, model pembelajaran dan karakteristik } \\
\text { peserta didik }\end{array}$ & $97,22 \%$ \\
\hline \multicolumn{1}{|c|}{ Rata-rata Total } & $93,63 \%$ \\
\hline
\end{tabular}

Pada indikator kelengkapan identitas silabus, dan kejelasan kompetensi inti dan kompetensi dasar memperoleh skor 100\% dengan kategori sangat valid, artinya kelengkapan identitas silabus dan kejelasan komponen inti dan komponen dasar telah sesuai dengan permendikbud No.22 Tahun 2016. Kesesuaian materi pembelajaran memperoleh skor sebesar 94,45\% dengan kategori sangat valid, artinya materi pembelajaran yang dikembangkan pada silabus sesuai dengan kompetensi dasar dan sistematis, serta pembagian materi pembelajaran yang dikembangkan pada silabus sesuai dengan kompetensi dasar. Kejelasan rumusan indikator pencapaian kompetensi memperoleh skor sebesar 100\% dengan kategori sangat valid, artinya rumusan IPK sangat sesuai dengan KD dan IPK terukur dengan menggunakan kata kerja operasional. Kesesuaian kegiatan pembelajaran dengan standar proses dan model CORE 
memperoleh skor sebesar 77,78\% dengan kategori valid, artinya kegiatan pembelajaran telah sesuai dengan langkah-langkah model CORE dan pendekatan saintifik. Kesesuaian penilaian hasil belajar memperoleh skor sebesar 91,67\% dengan kategori sangat valid, artinya teknik penilaian hasil belajar dalam silabus telah sesuai dengan kurikulum 2013. Kesesuaian sumber belajar dengan tujuan, model pembelajaran dan karakteristik peserta didik memperoleh sebesar 97,22\% dengan kategori sangat valid, artinya sumber belajar yang dikembangkan pada silabus cocok dengan karakteristik peserta didik dan tujuan pembelajaran. Secara keseluruhan skor hasil validasi silabus memperoleh skor 93,63\% dengan kategori sangat valid sehingga silabus yang peneliti kembangkan telah sesuai dengan Permendikbud No 22 Tahun 2016 dan berbasis model CORE. Adapun hasil validasi RPP oleh validator dapat dilihat pada tabel 3.

Tabel 3. Hasil Validasi RPP

\begin{tabular}{|l|c|}
\hline \multicolumn{1}{|c|}{ Indikator Penilaian } & Rata-rata \\
\hline Kelengkapan identitas RPP & $100 \%$ \\
\hline Kejelasan KI dan KD & $100 \%$ \\
\hline Kejelasan rumusan Indikator Pencapaian Kompetensi (IPK) & $100 \%$ \\
\hline Kesesuaian rumusan tujuan pembelajaran dengan indikator pencapaian & $100 \%$ \\
\hline Kesesuaian materi pembelajaran & $91,32 \%$ \\
\hline Kesesuaian kegiatan pembelajaran dengan standar proses & $97,86 \%$ \\
\hline Kesesuaian kegiatan pembelajaran dengan model CORE & $83,33 \%$ \\
\hline Kesesuaian kegiatan pembelajaran dengan KPMM & $96,19 \%$ \\
\hline $\begin{array}{l}\text { Kesesuaian alat, media, dan sumber belajar dengan tujuan, model pembelajaran } \\
\text { dan karakteristik peserta didik }\end{array}$ & $90,74 \%$ \\
\hline Kesesuaian penilaian hasil belajar & $96,53 \%$ \\
\hline Rata-rata Total & $95,60 \%$ \\
\hline
\end{tabular}

Indikator penilaian kelengkapan identitas RPP memperoleh nilai rata-rata $100 \%$ dengan kategori sangat valid, artinya komponen RPP sudah sesuai dengan Permendikbud No 22 tahun 2016. Kejelasan KI dan KD memperoleh nilai rata-rata 100\% dengan kategori sangat valid, artinya KI dan KD yang dikembangkan pada RPP sudah jelas dan tepat. Kejelasan rumusan indikator pencapaian kompetensi (IPK) memperoleh nilai rata-rata 100\% dengan kategori sangat valid, artinya rumusan IPK sangat sesuai dengan KD dan IPK terukur dengan menggunakan kata kerja operasional. Kesesuaian rumusan tujuan pembelajaran dengan indikator pencapaian memperoleh nilai rata-rata $100 \%$ dengan kategori sangat valid, artinya tujuan pembelajaran dapat diukur dan memuat komponen ABCD. Kesesuaian materi pembelajaran memperoleh nilai rata-rata 91,32\% dengan kategori sangat valid, artinya materi pembelajaran yang dikembangkan pada RPP sesuai dengan kompetensi dasar dan sistematis, serta pembagian materi pembelajaran yang dikembangkan pada RPP sesuai dengan kompetensi dasar. Kesesuaian kegiatan pembelajaran dengan standar proses memperoleh nilai rata-rata 97,86\% dengan kategori sangat valid, artinya kegiatan pembelajaran pada RPP telah memuat kegiatan pendahuluan, kegiatan inti dengan model CORE, dan kegiatan penutup. Kesesuaian kegiatan pembelajaran dengan model CORE memperoleh nilai rata-rata 83,33\% dengan kategori valid, artinya kegiatan pembelajaran di kegiatan inti telah memuat model CORE sesuai dengan tahap connecting, 
organizing, reflecting, extending. Kesesuaian kegiatan pembelajaran dengan kemampuan pemecahan masalah matematis memperoleh nilai rata-rata 96,19\% dengan kategori sangat valid, artinya dalam kegiatan pembelajaran peserta didik mampu memecahkan masalah dengan memahami masalah, merencanakan penyelesaian, menyelesaikan masalah dan memeriksa kembali. Kesesuaian alat, media dan sumber belajar dengan tujuan, model pembelajaran dan karakteristik peserta didik memperoleh nilai rata-rata 90,74\% dengan kategori sangat valid, artinya alat, media, dan sumber belajar yang dikembangkan pada RPP mendukung tercapainya tujuan pembelajaran. Kesesuaian penilaian hasil belajar memperoleh nilai rata-rata 96,53\% dengan kategori sangat valid, artinya aspek penilaian yang dikembangkan pada RPP sangat sesuai untuk mengukur ketercapaian kemampuan pemecahan masalah matematis. Secara keseluruhan skor hasil validasi RPP memperoleh skor 95,60\% dengan kategori sangat valid sehingga RPP yang peneliti kembangkan telah sesuai dengan Permendikbud No 22 Tahun 2016 dan berbasis model CORE.

Pengembangan perangkat pembelajaran berupa LKPD dibuat dengan model CORE pada materi bangun ruang sisi datar. Kegiatan pada LKPD dibuat menggunakan model CORE agar dapat membimbing peserta didik menemukan konsep dan memecahkan masalah. Berikut tampilan LKPD yang dikembangkan. Pengembangan tahap connecting dapat dilihat pada gambar 1 berikut.

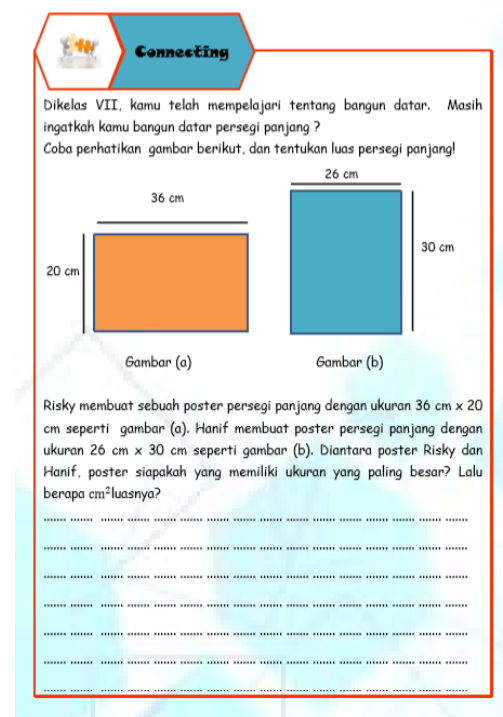

Gambar 1. Pengembangan Tahapan Connecting pada LKPD

Pada tahap connecting peserta didik diberikan stimulus dan situasi dimana guru membimbing peserta didik menghubungkan pengalaman atau pengetahuan sebelumnya yang pernah dipelajari dengan pengetahuan yang akan dipelajari peserta didik. Pengembangan tahap organizing dapat dilihat pada gambar 2 berikut. 


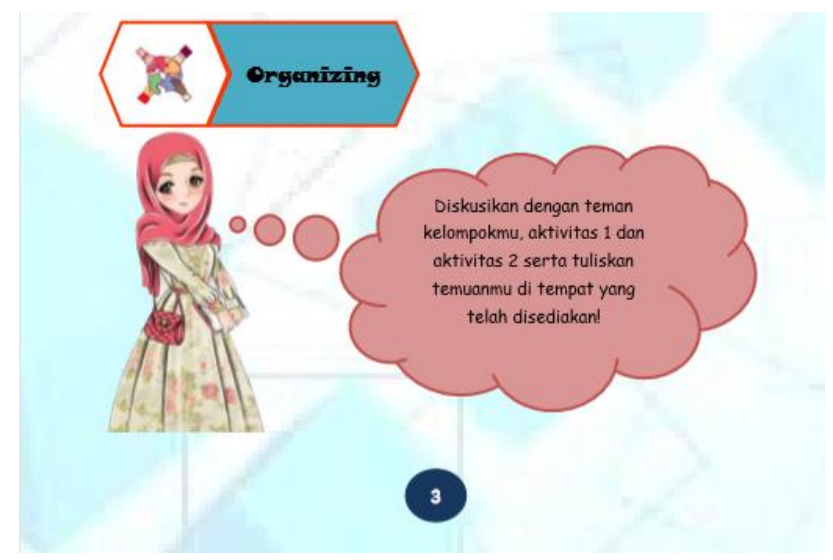

Gambar 2. Pengembangan Tahap Organizing pada LKPD

Pada tahap organizing guru meminta peserta didik untuk mengerjakan aktivitas yang menuntun peserta didik untuk menemukan pengetahuan baru dengan modal awal peserta didik dari pengalaman belajar sebelumnya. Pengembangan tahap reflecting dapat dilihat pada gambar 3 berikut.
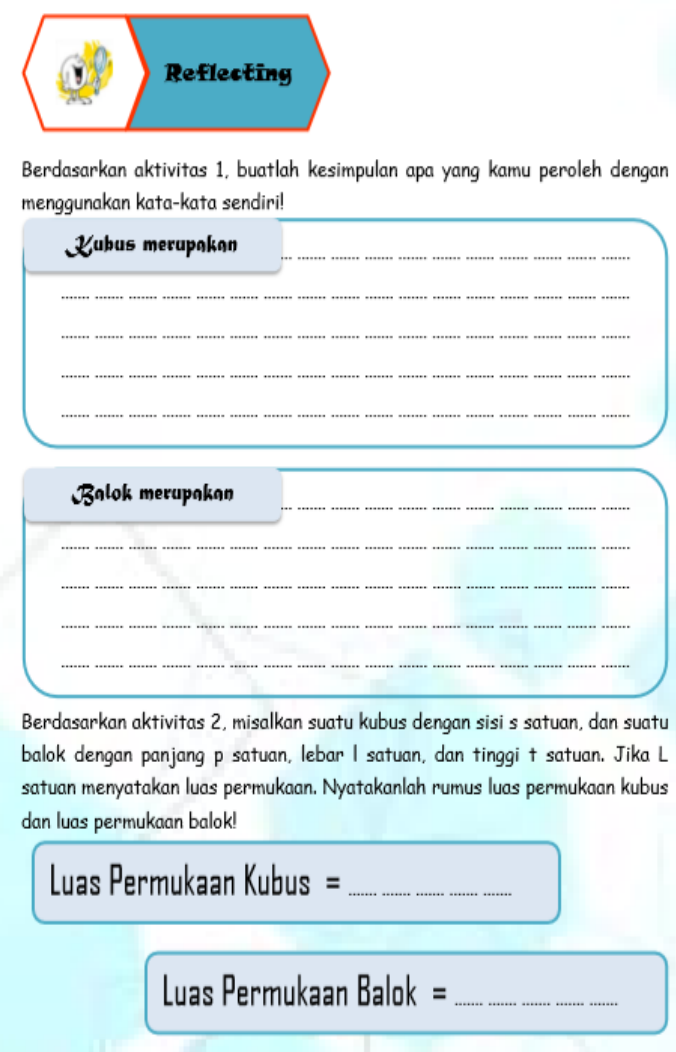

Gambar 3. Pengembangan Tahap Reflecting pada LKPD

Pada tahap reflecting guru mengarahkan peserta didik untuk memikirkan kembali temuan yang diperoleh pada tahap organizing, apakah pengetahuan yang diperoleh sudah tepat dan benar. Tahap ini peserta didik diminta untuk membuat kesimpulan dengan kalimat sendiri. Pengembangan tahap extending dapat dilihat pada gambar 4 berikut. 


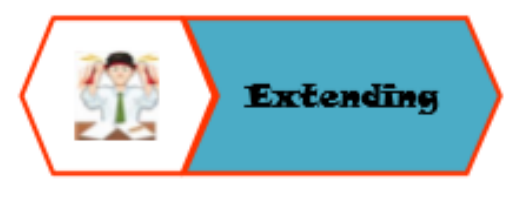

Kerjakanlah Latihan Soal Berikut ini secara mandiri.

1. Bu Lady membuat kue berbentuk kubus dengan panjang rusuk 20 $\mathrm{cm}$. Bu Lady akan memasukkan kue tersebut ke dalam kardus, Bu Lady akan membuat kardus sendiri menggunakan karton. Berapa luas minimal karton yang dibutuhkan bu Lady?

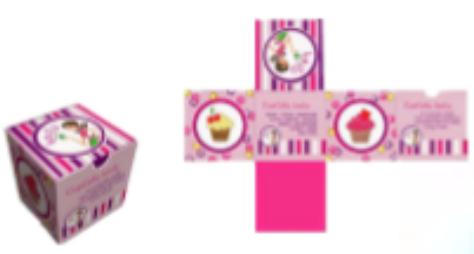

Gambar 4. Pengembangan Tahap Extending pada LKPD

Pada tahap extending guru meminta peserta didik untuk mengerjakan latihan soal di LKPD, pengetahuan baru yang diperoleh peserta didik diperluas melalui latihan soal. Adapun hasil validasi terhadap LKPD yang dikembangkan peneliti terlihat pada tabel 4.

Tabel 4. Hasil Validasi LKPD

\begin{tabular}{|l|c|}
\hline \multicolumn{1}{|c|}{ Indikator Penilaian } & Rata-rata \\
\hline Kelengkapan komponen LKPD & $100 \%$ \\
\hline Kesesuaian materi pembelajaran & $95,55 \%$ \\
\hline Kesesuaian LKPD dengan langkah-langkah Model CORE & $95,28 \%$ \\
\hline Kesesuaian LKPD dengan KPMM & $86,11 \%$ \\
\hline Kesesuaian LKPD dengan tingkat kemampuan peserta didik & $92,13 \%$ \\
\hline Ketepatan pemilihan kata dan bahasa yang digunakan & $91,67 \%$ \\
\hline Huruf yang digunakan di dalam LKPD & $86,11 \%$ \\
\hline Gambar yang disajikan di dalam LKPD & $84,03 \%$ \\
\hline Tampilan LKPD & $93,06 \%$ \\
\hline Rata-rata Total & $91,49 \%$ \\
\hline
\end{tabular}

Indikator penilaian kelengkapan komponen LKPD memperoleh nilai rata-rata 100\% dengan kategori sangat valid, artinya. Kesesuaian materi pembelajaran memperoleh nilai rata-rata 95,55\% dengan kategori sangat valid, artinya materi pembelajaran yang di LKPD sangat sesuai dengan tujuan pembelajaran dan karakteristik peserta didik. Kesesuaian LKPD dengan langkah-langkah model CORE memperoleh nilai rata-rata 95,28\% dengan kategori sangat valid, artinya kegiatan yang diberikan di dalam LKPD sangat sesuai dengan langkah model CORE. Kesesuaian LKPD dengan kemampuan pemecahan masalah matematis memperoleh nilai rata-rata $86,11 \%$ dengan kategori sangat valid, artinya LKPD yang digunakan sangat sesuai untuk menunjang kemampuan pemecahan masalah matematis peserta didik. Kesesuaian LKPD dengan tingkat kemampuan peserta didik memperoleh nilai rata-rata 92,13\% dengan kategori sangat valid, artinya LKPD yang dikembangkan bisa untuk semua peserta didik. Ketepatan pemilihan kata dan bahasa yang digunakan memperoleh nilai rata-rata 91,67\% dengan kategori sangat valid, artinya pemilihan kata dan bahasa di LKPD jelas dan mudah dipahami. Huruf yang digunakan di dalam LKPD 86,11\% dengan kategori sangat valid, artinya pemilihan huruf dan 
ukuran huruf jelas. Gambar yang disajikan di dalam LKPD memperoleh nilai rata-rata 84,03\% dengan kategori sangat valid, artinya gambar yang digunakan di LKPD jelas. Tampilan LKPD memperoleh nilai rata-rata 93,06\% dengan kategori sangat valid, artinya tampilan LKPD sangat menarik. Secara keseluruhan skor hasil validasi LKPD memperoleh skor 91,49\% dengan kategori sangat valid sehingga LKPD yang peneliti kembangkan berbasis model CORE telah memenuhi syarat-syarat pengembangan LKPD menurut Trianto (Trianto, 2009) yaitu syarat didaktik, syarat konstruksi, syarat teknis.

Tahap implementation, peneliti melakukan uji kelompok kecil terhadap LKPD yang dikembangkan kepada 8 orang peserta didik dengan kemampuan heterogen untuk melihat keterbacaan LKPD yang telah dikembangkan. Adapun hasil kepraktisan dari uji coba terbatas terlihat pada tabel 5.

Tabel 5. Hasil Kepraktisan Terhadap LKPD

\begin{tabular}{|l|c|}
\hline \multicolumn{1}{|c|}{ Indikator Penilaian } & Rata-rata \\
\hline Minat peserta didik dan tampilan LKPD & $90,74 \%$ \\
\hline Proses penggunaan & $90,19 \%$ \\
\hline Model CORE dan Kemampuan Pemecahan Masalah Matematis & $89,16 \%$ \\
\hline Waktu & $87,48 \%$ \\
\hline Evaluasi & $87,77 \%$ \\
\hline Rata-rata total & $89,07 \%$ \\
\hline
\end{tabular}

Secara keseluruhan hasil kepraktisan LKPD memperoleh skor sebesar 89,07\% dengan kriteria sangat praktis. Adapun tahap selanjutnya yang dilakukan peneliti adalah tahap evaluation, peneliti melakukan revisi terhadap perangkat pembelajaran selama proses validasi sesuai saran validator dan uji coba terbatas sesuai saran dari peserta didik. Keunggulan penelitian ini dengan penerapan model CORE yaitu peserta didik menemukan rumus sendiri, melatih daya ingat, dan peserta didik lebih termotivasi untuk mengikuti pembelajaran matematika serta dapat mengembangkan kemampuan pemecahan masalah matematis peserta didik dengan mengerjakan soal latihan.

\section{UCAPAN TERIMA KASIH}

Ucapan terima kasih disampaikan kepada semua pihak yang telah berperan dalam penelitian pengembangan perangkat pembelajaran matematika berbasis model CORE untuk memfasilitasi kemampuan pemecahan masalah matematis peserta didik SMP.

\section{KESIMPULAN}

Penelitian pengembangan ini menghasilkan perangkat pembelajaran berupa silabus, RPP, dan LKPD yang berbasis model CORE untuk memfasilitasi kemampuan pemecahan masalah matematis peserta didik SMP. Perangkat pembelajaran yang dihasilkan telah memenuhi kriteria sangat valid dan sangat praktis. Hasil kevalidan diperoleh berdasarkan penilaian yang diberikan validator ahli terhadap perangkat pembelajaran sedangkan hasil kepraktisan diperoleh dari hasil angket respon peserta didik terhadap LKPD yang dikembangkan. 
Berdasarkan kesimpulan dan hambatan yang ditemui selama penelitian, maka saran peneliti adalah sebagai berikut yaitu (1) perangkat pembelajaran matematika (silabus, RPP, dan LKPD) yang dikembangkan dalam penelitian ini telah memenuhi kriteria valid dan praktis, sebaiknya peneliti lain melanjutkan uji efektivitas; (2) perangkat pembelajaran matematika yang dikembangkan dalam penelitian ini masih terbatas pada materi bangun ruang sisi datar, sehingga tidak menutupi kemungkinan bagi peneliti lain untuk mengembangkan perangkat pembelajaran matematika dengan materi yang lain.

\section{REFERENSI}

Abdurrahman, M. (2012). Anak Berkesulitan Belajar: Teori, Diagnosis dan Remediasinya. PT. Rineka Cipta.

Akbar, S. (2013). Instrumen Perangkat Pembelajaaran. Remaja Rosdakarya.

Al Humaira, F. (2014). Penerapan Model Pembelajaran Core Pada Pembelajaran Matematika Siswa Kelas X SMAN 9 Padang. Jurnal Pendidikan Matematika, 3.

Azizah, L., Mariani, S., \& Rochmad, R. (2012). Pengembangan Perangkat Pembelajaran Model CORE Bernuansa Konstruktivistik untuk Meningkatkan Kemampuan Koneksi Matematis. Unnes Journal of Mathematics Education Research, 1(2).

Benny A. Pribadi. (2010). Model Desain Sistem Pembelajaran. Dian Rakyat.

Haholo, S. . (2016). Analisis Kemampuan Pemecahan Masalah Ditinjau dari Gaya Kognitif Siswa pada Model Pembelajaran Missouri Mathematics Project. Universitas Negeri Semarang.

Konita, M., Asikin, M. \& Asih, T. S. N. (2019). Kemampuan Penalaran Matematika dalam model pembelajaran Connecting, Organizing, Reflecting, Extending (CORE). Semarang, PRISMA. Prosiding Seminar Nasional.2, 611-625.

Kunandar. (2014). Penilaian Autentik. Rajawali Pres.

Linggar, G., M., Budi, M. (2016). Kemampuan Pemecahan Masalah Matematika Aljabar Berbasis TIMSS Pada Siswa Kelas VIII. Prosiding Seminar Nasional Pendidikan Matematika.

Mulyatiningsih, E. (2012). Metode Penelitian Terapan Bidang Pendidikan. Alfabeta.

NCTM. (2000). Principles and Standards for School Mathematics. Reston, VA: The National Council of Teacher of Mathematics.

Noorlaila, Danaryanti, A., \& Mawaddah, S. (2018). Kemampuan pemecahan masalah matematis siswa dengan menerapkan model pembelajaran. Seminar Nasional Pendidikan Matematika, 162-168.

OECD. (2014). PISA 2012 Assessment and Analytical Framework: Mathematics, Reading, Science, Problem Solving and Financial Literacy. OECD Publishing.

Permendikbud Nomor 58 Tahun 2014 tentang Kurikulum SMP. (n.d.).

Prastowo, A. (2010). Panduan Kreatif Membuat Bahan Ajar Inovatif. DIVA Press.

Sa'adah, D., Masrukan, M., \& Kuniasih, A. W. (2017). Pengembangan Perangkat Ajar Model Core Pendekatan Metakognitif untuk Meningkatkan Kemampuan Pemecahan Masalah Geometri Kelas VIII. JURNAL E-DuMath, 3.

Shoimin, A. (2014). 68 Model Pembelajaran dalam Kurikulum 2013. AR Ruzz. 
Suyatno. (2009). Menjelajah Pembelajaran Inovatif. Mamedia Buana Pustaka.

Trianto. (2009). Mendesain Model Pembelajaran Inovatif - Progresif. Kencana Prenada Media Group.

Ulfa Aulia. (2015). Pengembangan LKPD Berbasis Model CORE dengan Pendekatan Saintifik pada Materi Relasi dan Fungsi Kelas VIII SMP. Universitas Jambi.

Ulya, H. (2016). Profil kemampuan pemecahan masalah siswa bermotivasi belajar tinggi berdasarkan ideal problem solving. Jurnal Konseling Gusjigang, 2. 